\title{
“The Scarlet Letter”-The Annotation of the Human Morality
}

\author{
Mingming Li \\ Baicheng Normal University, School of Foreign Language, Baicheng, Jilin, China, 137000
}

Keywords: "Scarlet Letter"; Religious View; Ethics; Moral Interpretation

\begin{abstract}
Through the analysis of the four main characters in the Scarlet Letter, this paper studies the rich moral connotation of the characters and then interprets the problems of human morality. At the same time, the text also permeates the religious culture, and the contradictory complex religious thoughts influence the moral connotation and the interpretation of human morality. From the text of the four heroes of the moral step by step from the "fall" to "repentance" in the development of the author exposed the cruelty of religion and the lack of human morality, so as to celebrate the pursuit of good moral goals of mankind.
\end{abstract}

\section{Introduction}

"The Scarlet Letter" is the famous romantic writer Nathaniel Hawthorne's excellent masterpiece at nineteenth century. This novel is based on adultery in New England, around these heroes love hate to start, portrayed with profound moral connotation of the characters. "The Scarlet Letter" is a love tragedy, but it goes beyond love and becomes an interpretation of moral works. In the history of European development, religion is ubiquitous. In particular, the religious culture permeates the literary works with its rich ideological connotation. Hawthorne often used the historical society of colonialism as the background material of the novel, the liberation of individuality and the protest of human resistance prevailed over religious paranoia, and prevailed over the prejudice of moral custom. He wrote many novels in his life, of which the "Scarlet Letter" is the most representative work, this novel embodies Hawthorne's ideological system and moral values: he must have the role of religion to purify the human ethic, but also exposed the paranoid side of religion. His thoughts are full of contradictions and complexities, but he always believes that human morality continues to improve in development. "Scarlet Letter" represents the highest achievement of Hawthorne, called a classic full of moral meaning.

\section{The Introduction of Writer and Works}

Hawthorne is the famous nineteenth century romantic novelist. His early short stories mainly include "ancient house moss" "young man Brown" and other works. From 1850 he has published four novels: "The Scarlet Letter" "There are seven sharp corners of the house" "Fuku legend" and "jade statue". "Scarlet Letter" is the classic among the four novels. "The Scarlet Letter" This work is simple, but its rich moral connotation has always been worthy of our thought, the author gives a few heroes of different moral connotations. But how did the author explore human morality through these individuals? The following describes the relationship between the works and the characters to see how the writers in the characterization of these characters to interpret human morality.

The novel is the story of New England in the seventeenth century. The young and beautiful Hester Prynne marries the ugly scholar Qi Ling Woos, whose marriage has no love. She cannot feel the family's happiness and warmth. Two years ago, Hester was separated from her husband. Husbeth fell in love with the young and talented priest and was put into prison because of adultery. In the then New England, under the system of church and state, the church and the people could not tolerate such a bold rebellious love. Hester was brought to the execution ground and refused to say the same prisoner. At this time and his separated husband for many years in the audience to see 
everything, in the name of his doctor to the prison to ask Hester to say the name of the same prisoner, but was rejected by Hester. He vowed to find an adulterous husband and a frantic retaliation against the two. The priest did not come forward to admit that he was committed with Hester in the execution ground, and the priest was tortured by the cowardice. When Zillingworth discovered that the pastor was his wife's lover, he unfolded the retaliation against the priest, and the priest fell into great pain. After seven years of painful torture, the priest finally bravely with Hyster and their daughter - Pearl walked on the desk to admit his own crime, then fell to the ground. A year later, Zillingworth also lost the meaning of survival and died. Pearl grew up after not affected by their parents, but live a happy life. Hyster returned to Boston after many years and re-wore the red horns in that dilapidated hut to stick to the end of life.

\section{The Author 'S Creative Thought}

The birthplace of the city of Salem, Massachusetts is the famous "exorcism" of American history. The author was born in New England's dilapidated aristocratic family, the ancestors are the Puritans. Although he is not a Puritan but deeply influenced by the Puritan thought and it cannot get rid of the concept of Puritanism to look at morality. In the moral concept of the writer permeated with the rich Puritanism, especially the "original sin": "God is omnipotent, people are insignificant, and for the source of all evil. God create people and it was in accordance with the style of God but the resurrection of God's perfection, but because of the fall of Adam destroyed the glory of God's whole natural program, is a man away from God. "[1] and" Scarlet Letter" In the description of the main characters are fully embodies the Puritan thought on the impact of Hawthorne. But he is a strong humanistic thinking of the people, so his creative thinking is full of contradictions and complex. On the one hand, he believes in "the original sin," that all people are born and guilty, need to rely on God's faith and the corresponding crime to obtain salvation. He has a positive side for Puritanism, but he is more opposed to the extreme, paranoid and harsh side of Puritanism. It is because of the contradiction of his thought that the four main characters in the work break through the single pattern of the characters at the same time, and make each character a carrier of moral interpretation, giving the rich moral connotation. The moral thought of this literary works and the image of the hero is indivisible. The following analysis of the main characters in the novel explains the connotation of human morality.

\section{The Moral Implication in the Characters}

The Fallen Angel - Hyster Prynne. Hester is the image of the female portrayed by the author. In the author's pen, she is not like a sinful sinner, but more like a fight for freedom, happy female warrior. In her body fully embodies the rebellion of religion. When she faced no love marriage, she chose to leave. She and young chic, handsome priest love, due to committing adultery committed Pearl. In the eyes of others, she is a wife who abandons the family, the mother of the illegitimate woman, and the betrayal of the adultery. Though it is because of the loyalty of the loved one and the faithfulness of love that makes her have a frivolous and confused side of human nature, all this cannot conceal her beautiful, innocent and kind.

Mr. Su said: "Hawthorne seems unable to make a clear moral judgment on Hester." [2] But I think the author always has a positive attitude towards Hester and gives full sympathy. The author uses the moral qualities of Hester to build the moral thoughts of the works. Hawthorne first placed Hayes in a guilty person, believing that she should be punished. And then let her bear all the pain and torture, living in the condemnation of the world, and finally through their own virtue and quality to win the recognition of the world, so as to complete her moral new life. Marx said, "The essence of man is a real social relationship." [3] Individuals only in the community can be positioned for their own, to achieve the value of existence. Out of the society he lost the meaning of existence. After the indictment, Hester did not leave this place to make her shame but chose to stay. And Zhijie stay away from good practice, even if people sometimes maliciously bully her, but she always with a wide attitude to face everyone, even do not seek return, without any complaints to 
accept everything. From her good people began to really understand her moral character.

When the church system was so cruel, she believed in divine love. She refused to speak the same prisoner without any complaint. For love, she can endure all the pain in the world, neither overbearing nor overbearing. Hyster is a woman who pursues freedom, personality liberation and true love. The opening of the novel focuses on the appearance of Hester's appearance. "She is tall and tall, her face is beautiful and beautiful, looks beautiful and charming, charming and moving, chest wearing a humiliation mark is not the slightest shame, but there is a lady's Charm ". [4] Even those who embrace her with the image of the Virgin Mary. The author gave Hyster innocence, good character. Hyster is not only reborn on the appearance and in the fight for custody of the daughter is also the same bold. When the governor of Bellingham and the church thought she was not qualified to raise Pearl, she protested and glared at Puritan's chief. She knew that Pearl was the sign of her sins and shame, but she was desperate to fight for a mother's right, bravely bear the responsibility of a mother, fully embodies her is a love of love, dare to fight for life of women.

At the end of the novel, Hester returned to Boston for many years and returned to the house where she once lived, and wore the scarlet that stifled her. At this point her chest is no longer a sign of shame, and become a symbol of virtue. "The Bible" pointed out that after suffering, through the redemption of original sin, good deeds, people will return to the Garden of Eden after death. [5] In Hawthorne appears that crime is on the one hand, and more importantly, the different attitudes towards the evil of the people. Hester's virtue and quality continue to deepen and sublimate in the novel. Hester is no longer a sinner but a moral incarnation. Her scarred A is also turned from adultery into Angel's alias and even admiration (Admirable). The angel came from the kingdom of heaven, and through her own actions she made her soul pure and redeemed her fallen soul.

The Revenge Devil - Qi Ling Woosi. The image of Zillingworth and Hester's are in sharp contrast. He is a deformed, metamorphosis of the vengeance of the devil. He was young ignorant in Hester, difficult to distinguish between right and wrong, ugly and versed in Qi Ling Wo Si married her wife. He does not care about her, not love her. He is only concerned about her beauty and her dignity, and irresponsible will be a young and beautiful woman sent to the colonies of North America alone, but they remain in Europe. His irresponsibility led to the subsequent tragedy. In this lack of love of marriage, Hester's betrayal is an injury to him, he can be said to be a poor victim. We should have him with the mercy of sympathy and sympathy. But he is not worthy of sympathy and forgiveness for his revenge, loss of reason, frenziedness, the use of his own wisdom to create evil, into a vengeance of the devil, is not worthy of sympathy and forgiveness.

When he was in the crowd before the crowd in the crowd peeps to her husband, he began his revenge plan, into a real sinner. In order to achieve his revenge plan, he pretends to be a doctor, a glimpse of Dimmesdale's inner secret. When he found that Dimmesdale's chest had the same red word as Hyster, his ecstasy made him lose his humanity. He built happiness on the pain of others, torturing others to achieve their purpose of retaliation. In the minds of Westerners, the inner heart is inviolable. The body of the body can accept any torture and suffering. However, Chi Ling Woos insidious fraud is in violation of the most holy land committed the unforgivable sins. After the death of Timothy Dyer, he died quickly in the loss of aging. He thought that his retaliation was psychologically compensated, but he was not so happy to get death.

The wickedness of Zillingworth brought great pain and torture to Hyster and Dimmesdale. Hester's betrayal made him desperate, and the presence of Dimmesdale made him crazy. He is like a devil in the crazy revenge and destroy the world of others beyond redemption. The author in the appearance will be described as a short stature, face ugly gray guy, like the strange wear of psychological pervert, is extremely commensurate with him. At the end of the article, the author confessed his ending: "The death of Zillingworth, he left a considerable amount of property in North America and England to the daughter of Hester Prynne - Pearl ". [6] Hawthorne showed us a very memorable ending. His action may be his repentance of the sins of life, the guilty of the same can also use good to purify their unclean soul. This may be his extremely selfish hypocrisy, despicable dirty life in the only little good light.

Twist of Humanity - Dimmesdale. Dumesdale is a pastor, a devout Puritans. His career is the 
most holy of the sun. People worship him, and even think he walked the road, lived in the house are sacred and inviolable. He is seen as a spokesperson for God. He is knowledgeable, handsome and devout religious beliefs, but he is a secret sack of religious coat.

He knew that he could not marry Hester as a wife, and that he kept their romance growing, and that they had committed an unforgivable sin because of their lust. This crime is seriously inconsistent with his position, which is a great insult to God and the greatest deceit of the believer. If Hyster is an open sinner, then he is a secret sinner. As a man, he should share the pain and humiliation for Hester. As a father, he should give Pearl a fatherly love, raising children healthy growth. From Hester at the desk to admit that his crimes began, he abandoned the love for Hester, the love of the children. Choose to use cold to return them. He dare not bear his own crime and this is a serious selfish behavior. He was afraid to lose his reputation, status and future, so he concealed his own crime. His selfish behavior was in stark contrast to Hyster's admiration for his selflessness. When Hester's denial and alone bear humiliation and rap, gave his heart had a strong shock. "Self-blame and cowardice are like a pair of siblings and close friends, and whenever an impulse urges him to confess everything, the latter shakes him back to reality with trembling hands." [7] He tried to use hypocritical repentance to make his own sins reduced, but the more he repented his pain the deeper, the more serious his sense of guilt. He designed a series of atonement for himself, such as "self-lashing", "hunger strike" and "midnight atonement", which are self-deceiving. His hypocrisy and cowardice made him lose the glory of human nature.

Compared with Zillingworth, the sins committed by Dimmesdale are different. The sins committed by Dimmesdale are not born by love. Zillingworth to Hyster is a no love of marriage, no sense of security of the family. He is a husband with no sense of responsibility. The love of Hindesdale to Hester is warm and real. For example, in the later night tour and Hester meet, especially in the forest meet and meet the truth when fled. His performance made him feel surprised. These are reflected in the Dimmesdale on the Hyster is love and responsibility, it is clear that he was affirmed in the heart of Hester, just out of cowardly afraid to admit it. With the glittering and interrogation of Zillingworth's side beating, he was depressed all day long. The moral sense of responsibility made his heart overwhelmed, and finally seven years later he went to the show, admitting his own crime. As his own words: "My sorrow, my sins, my pain is with me, and the earthly part is buried in my grave, and the part of the spirit will go with me to the eternal realm." [8]

Dumesdale gained the salvation and liberation of the soul with the heavy cost of life, and in the moment his life fell to the ground, he completed the spiritual transformation. "Death" for him is not the end of life but the soul of the newborn. A hypocritical and weak people with honest and courageous in exchange for the inner peace, scrub their own evil.

As the writer wrote at the end of the novel: "We can learn a lot from this poor pastor, and we can put this into one sentence: honest! Honest! Honest! Frank face this world, if you cannot put yourself The most iniquity of sin to show to others, then at least to show a clue in order to allow others to take this to infer your sins! "[9]

The Wizard of the Forest - Pearl. In the "red word" three heroes love and hate, good and evil intertwined, Pearl has a unique meaning.

For Hester and Dimmesdale, Pearl is the living "Scarlet Letter". When Hester threw the red word on the ground, Pearl wanted her mother to pick it up. Otherwise she would not recognize Hester as her mother or ignore her mother. At the same time her presence is always reminded that Timothy Dyer should be confronted with reality. His hypocrisy made Hester a humiliation. His cowardice made an innocent child a sign of sin. His selfishness allowed their mother and daughter to be discriminated against, and his repentance might be useful to Hyster because they were guilty and guilty. But for any innocent child, any repentance of him is futile. Finally, at the request of Pearl, Dumesdale pleaded guilty with the mother and daughter in the public during the day. The face of a child on a family of three warm desire how he can refuse, so her request to achieve! Although he is the cost of life to achieve, but he is happy, satisfied. Pearl gave their sinful soul a new life.

In the case of Livinsworth, Pearl has a purifying effect on his evil. In his sinister revenge, he did not retaliate against Pearl, but there have been some good performance. For example: "He had 
carefully prepared a good syrup, as in the prison as the father of the same drug for her until she sank into the sweet sleep." [10] His dying wills were written, leaving all his inheritance to the bead. Whether he is out of any idea, have proved that in the treatment of Pearl here, his conscience is not devoid of human nature is not completely lost. In the last of his life has been repentant, so that their evil souls become pure some.

For the time of the community, Pearl reflects the social morality at that time. In the eyes of the Puritans, Pearl was abandoned by this society. People regard her as a wild boy, the same age children bully her and she wants to endure the rumors of the world. However, Pearl is not like a child of the world, but like a wizard, she is full of vitality. Her unrestrained bullying her children were afraid, the Puritans felt uneasy, leaving the cold world to show the ugly prototype. Her appearance to the social moral problems can be concentrated, so that we can think about the moral aspects of this society.

Hawthorne gives Pearl a perfect destination for happiness. Letting her start another life in another place, which has a tendency in the emotions expressed by the author. Tend to freedom, happiness, emotion, the pursuit of society. He starts from the personality of Pearl and then exposes the dark side of Puritanism, and then interprets the human moral problems.

\section{Conclusion}

"The Scarlet Letter" is a classic interpretation of human ethics. The author has the ability to transcend time and space when discussing human moral issues. Hawthorne put the concept of religion into the characters, to enrich the moral connotation of the characters. In his view, people are not perfect? The good and the evil of human nature is not immutable, but flow between the two. Human morality is both weak and glorious. The author in the interpretation of human morality through the text of the three heroes in different ways wants to obtain their own soul salvation, so that their morals continue to deepen, and thus play an exemplary role in human ethics. Whether you are guilty or not, people should be through their own unremitting efforts to achieve their own moral perfection. Human morality in the ugly, hypocritical, evil, etc., these are we want to abandon, and good, honest, beautiful, freedom and so are we want to pursue the goal. Hawthorne is through the disclosure of human nature and human morality in the ugly, to celebrate the purity of human morality, let us accept the moral baptism, and then gets the moral perfection.

\section{References}

[1] [5] Lei Yongming. Si Gao Bible of the book [M]. Beijing: Si Gao Bible Society, 1968: 58,428.

[2] Su Yuxiao. Evil and Redemption: Hawthorne's "Scarlet Letter" Christian Ethics Interpretation [J]. Foreign Literature Studies, 2007 (4): 4.

[3] Selected Works of Marx, Engels, Marx and Engels [M]. Beijing: People's Publishing House, 1995: 530.

[8] [7] [8] [9] [10] Hawthorne (with), Yao Naiqiang translation. Scarlet Letter[M]. Nanjing: Translation Lin Publishing House, 1998: 3, 181, 68, 172, 180, 10 